Nāgārjuna's Twelve Gate Treatise 


\section{Studies of Classical India}

Editors:

Bimal K. Matilal

Spalding Professor of Eastern Religions and Ethics, Oxford University, England

J. Moussaieff Masson

Professor of Sanskrit, University of California, Berkeley, Calif., U.S.A.

Editorial Board:

Etienne Lamotte

University of Louvain, Belgium

Daniel H. H. Ingalls

Harvard University, Cambridge, Mass., U.S.A.

John Brough

St. John's College, University of Cambridge, England

Volume 5 


\section{Nāgārjuna's \\ Twelve Gate Treatise}

Translated, with Introductory Essays,

Comments, and Notes

by

Hsueh-li Cheng

Dept. of Philosophy and Religious Studies,

University of Hawaii at Hilo

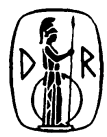

D. Reidel Publishing Company

Dordrecht : Holland / Boston : U.S.A. / London : England 
Nāgārjuna, 2nd cent.

Nāgārjuna's Twelve gate treatise.

(Studies of classical India ; v. 5)

Translation of: Dvādaśanikāyasāâstra.

Bibliography: $p$.

Includes indexes.

1. Mādhyamika (Buddhism) I. Cheng, Hsueh-li. II. Title. III. Series. BO2782.E5C47 1982

ISBN-13: 978-94-009-7777-8 294.3'85 82-9858

DOI: $10.1007 / 978-94-009-7775-4$

Published by D. Reidel Publishing Company, P.O. Box 17, 3300 AA Dordrecht, Holland

Sold and distributed in the U.S.A. and Canada by Kluwer Boston Inc., 190 Old Derby Street, Hingham, MA. 02043, U.S.A.

In all other countries, sold and distributed by Kluwer Academic Publishers Group, P.O. Box 322, 3300 AH Dordrecht, Holland

D. Reidel Publishing Company is a member of the Kluwer Group

\section{All Rights Reserved}

Copyright $\odot 1982$ by D. Reidel Publishing Company, Dordrecht, Holland Softcover reprint of the hardcover 1st edition 1982 No part of the material protected by this copyright notice may be reproduced or utilized in any form or by any means, electronic or mechanical, including photocopying, recording or by any informational storage and retrieval system, without written permission from the copyright owner 


\section{TABLE OF CONTENTS}

Introduction vii

Preface 1

1. Nāgārjuna and the Spread of His Teachings 4

2. San-lun Approaches to Emptiness 13

3. The Nature and Value of the Text 27

$\begin{array}{ll}\text { Notes } & 37\end{array}$

NĀGĀRJUNA'S TWELVE GATE TREATISE

Table of Contents [Seng-jui] 47

Preface [Seng-jui]

I. Causal Conditions 53

II. With or Without Effect 59

III. Conditions $\quad 70$

IV. Characteristics 72

V. With or Without Characteristics 79

VI. Identity or Difference 81

VII. Being or Non-being $\quad 85$

VIII. Nature $\quad 89$

IX. Cause and Effect 92

X. The Creator 93

XI. The Three Times 101

XII. Production 104 
$\begin{array}{ll}\text { Notes } & 108\end{array}$

$\begin{array}{lr}\text { Glossary } & 119\end{array}$

List of Chinese Terms 131

$\begin{array}{ll}\text { Selected Bibliography } & 135\end{array}$

Index of Names 142

Index of Subjects $\quad 144$ 


\section{INTRODUCTION}

\section{MĀDHYAMIKA}

The hallmark of Mādhyamika philosophy is 'Emptiness', śünyatā. This is not a view of reality. In fact it is emphatically denied that śünyatā is a view of reality. If anybody falls into such an error as to construe emptiness as reality (or as a view, even the right view, of reality), he is only grasping the snake at the wrong end $(M k$, 24.11)! Nāgārjuna in $M k, 24.18$, has referred to at least four ways by which the same truth is conveyed:

Whatever is dependent origination, we call it emptiness. That is (also) dependent conceptualization; that is, to be sure, the Middle Way.

The two terms, pratītya samutpāda and upādāya prajñapti, which I have translated here' as 'dependent origination' and 'dependent conceptualization' need to be explained. The interdependence of everything (and under 'everything' we may include, following the Mãdhyamika, all items, ontological concepts, entities, theories, views, theses and even relative truths), i.e., the essential lack of independence of the origin (cf. $u t p \bar{a} d a$ ) of everything proves or shows that everything is essentially devoid of its assumed essence or its independent 'own nature' or its 'self-existence' (cf. svabhāva). Besides, our cognition of anything lacks independence in the same way. Our conception (cf. prajñapti) of something $a$ essentially depends upon something $b$, and so on for everything ad infinitum. Emptiness is thus shown in both ways, from the ontological point of view and from the epistemic point of view. Sometimes, this is expressed in the form of an argument: The truth of everything is emptiness because of the dependent origination of everything. (Compare the introductory comments of Nāgārjuna in 
Vigrahavyāvartanī.) The above description, shorn of its awkward technicalities inherited through translation, from the style of the original Sanskrit formulation, can be re-stated for moderners as follows. The Mādhyamika argues that what we might call 'the absolute conception of reality' should be regarded as entirely empty. An absolute conception of reality - a reality which all representations represent but is itself independent of them - is what is presupposed by our traditional natural science and also forced upon us by our very conception of Knowledge. Knowledge, understood as distinct from error etc., is presumably knowledge of a reality that may exist independently. It is knowing what is there anyway, and what is there anyway is supposed to be unaffected, unmodified, by our knowing it in any particular way. And know we must always in some particular way or other.

Assuming that we wish to combat solipsism or some extreme form of idealism, we may put the point in another way. We seem to have a determinate picture of the world, what it is like, independent of any Knowledge, i.e., any representation of it in thought, any conceptualizations, beliefs, experiences and assumptions. But that picture is ever elusive to us, for we have only different, endless representations of it. No matter how deeply we may think, we may only have another representation of it in thought. It seems that each representation, barring gross absurdities and incoherence, could claim to be 'knowledge', and, what is worse, there is no vantage point from which we have an absolute representation of reality. Our conception of knowledge unfolds the implicit paradox: it projects the conception of an independent reality but also turns it into an ever receding picture - a mirage. No representation can provide finally sufficient substance to that picture. An absolute conception of reality is therefore empty a 'truth' that dawns upon us as it did, so it is claimed, to the final meditative insight of the Mādhyamikas.

Emptiness or vacuity seems to be at times horrifying, and, to be sure, at times attractive and alluring. The modern man, particularly the Western man, finds this boldness to be rather intriguing and it evokes two very different sorts of response or reaction. There 
are those who find in such forms of Buddhism an escape route from everything that they need to get away from, dogmas, superstitions, irrational beliefs, faith and even rationality! For emptiness seems to change the very meaning of rationality. Lao Tzu begins Tao Te Ching with this verse: ${ }^{1}$

The Way that we can talk about or describe is not the Way.

I am not sure whether the Taoist and the Mãdhyamika meant the same thing, but undoubtedly they used very similar language to say what they wanted to say. This contributed to the creation of the Western notion of 'Oriental mysticism' as the take-off point to the realm of irrationality. Those who boast of Western rationality, therefore, find such Buddhism positively repulsive and maddening. It is, they claim, the realm of 'illogic', and therefore, of insanity. Both of these attitudes towards Mādhyamika philosophy are wrong and misleading. Both of them grab, to repeat Nāgārjuna's own imagery, emptiness at its wrong end. I do not need to repeat Nāgărjuna's cynical warning: Emptiness grabbed at the wrong end is like a snake grabbed at its tail; it is fatal.

The philosophy of emptiness is not a regress into the primordial chaos of irrationality. It is true historically that Mādhyamika supplied the broad philosophical basis for various forms of Buddhist practices ranging from pure meditation to exotic Buddhist Tantra rituals for ecstasy. But this will be a subject for historians, not philosophers. What should interest the philosophers today is the fact that Mãdhyamika philosophical texts (and the present text is a good specimen) constitute undoubtedly an important component of our global heritage in philosophy. Mãdhyamika is a valuable expression of human rationality. This point needs to be stressed in order to counteract the widespread Western misconception to the effect that Mādhyamika is of a piece with the so-called irrational Oriental mysticism. Mādhyamika, for me, is philosophy, i.e., an integral part of what we call today philosophic activity. It is akin to the position of radical scepticism 
only if a radical sceptic can be said to have a position at all. I do not see how a radical sceptic can consistently hold to a position that can be formulated and defended. And the Mãdhyamika will say 'OM' (= Ditto). Nāgārjuna says in Vigrahavyāvartanì (v. 29):

I have no pratij $\tilde{n} \bar{a}$ (= proposition, position) to defend.

Mādhyamika is sceptical of all philosophical doctrines, tenets, categories. It could be argued that Mādhyamika is therefore not philosophy, it is anti-philosophical. I consider this argument to be fallacious. If 'philosophy' is understood to mean broadly rational discourse on demonstrable answers to some meaningful questions, Mādhyamika certainly falls into this category. Philosophy is one of the few disciplines which turns to itself. A comparison comes to my mind. It is a comparison with the discipline called 'natural theology'. Anthony Kenny has recently written (The God of the Philosophers): ${ }^{2}$

... If we take natural theology to be philosophical analysis of the concepts used in thinking and talking about God, then a disproof of God's existence, or a demonstration that the very notion of God was incoherent, would itself be a successful piece of natural theologizing. (p. 4, Oxford, 1979).

The Mădhyamika attempt to show that all philosophical (or even common-sensical) views of reality are basically incoherent would, I assert, be also a successful piece of philosophizing in the same manner.

\section{VITANḌ̄ $\bar{A}$}

A few words about the nature of the philosophical arguments used by the Mādhyamikas may be in order here. Their method of argument belonged undoubtedly to the tradition of philosophic debate ( $v \bar{a} d a$ or vivāda tradition) that evolved out of the earlier tradition of sophistry and eristic. In a philosophic debate, the general strategy is to refute (cf. dūṣana) the rival positions, and 
establish and defend (sthäpana) the philosopher's own position. A sceptic or a Mādhyamika excelled in the first (dūssana). In fact, the second was thought by some either unnecessary (e.g., one might formulate one's own position but not think it necessary to establish or defend it, cf. the Advaita Vedānta of Sriharsa) or impossible or both (e.g., a true sceptic, or even a Mādhyamika, in order to be consistent, had to say that he was unable to formulate his position for there was no position he held to). This type of debate where refutation was the only game that could be played was called vitanḍa (cf. Nyāyasütra, 1.2.3). ${ }^{3}$

Vitand $\bar{a}$ was obviously used in a pejorative sense as is evident from the comments of the Naiyāyikas like Vātsyāyana. A debater who indulged in vitand $\bar{a}$ was pictured generally as an iconoclast, who had nothing at stake, or was a motiveless, maligning sort of person. But this was both incorrect and unfair when we think of such philosophers as Nāgārjuna, Sañjaya (an agnostic), Jayarāsi (a sceptic) and Śìharșa (a Vedāntin), who restricted their philosophic activity to the 'refutation only' kind of debate (vitandā). Elsewhere I have shown that the later Nyāya tradition acknowledged this fact and said that the 'refutation only' kind of debate can also claim philosophical respectability. ${ }^{4}$

\section{PRASAṄGA}

The argument-pattern used by the Mādhyamikas as well as other debaters was called prasanga. It literally means an implication or a consequence, but it is used in the technical sense of an argument that has undesirable and unacceptable implications, or leads to absurd consequences. In fact, a position (or, a philosophic concept) is here examined in the light of one or several alternative (and mutually exclusive) interpretations or formulations and it is shown that in each case we end up with some absurdity or other. Hence the position is refuted, for otherwise the argument will lead to an absurd situation. In this general sense, therefore, we can call it a reductio.

How can one refute all positions? Is it not itself a position: 
refutation of all positions? If we say that there is no fact of the matter, is it not another fact of the matter? How can we avoid this obvious paradox? I have discussed elsewhere how a Mādhyamika can avoid the paradox or how a radical form of scepticism can be made consistent. ${ }^{5}$ Briefly speaking, a debater can go on refuting all possible, and formulable, positions each at a time and then, when no position is forthcoming, can stop without making the obvious claim that all positions have been refuted, for the mere statement of that claim would engender a new position that needs to be refuted again. Obviously we cannot make noise crying out 'Silence!' when all noise-makings have already stopped, for if we did, another shout of 'Silence!' would indeed be needed to silence the first shouting. And then another and another. Nāgārjuna himself uses this analogy of silence and noise-making in his Vigrahavyāvartani (verses $3,4,25$ ) to make the same point.

The second point that needs to be made in this connection is that refutation here need not, and should not, be construed as the standard logical negation of a position or proposition. It seems better to view such a refutation as an illocutionary act in the manner suggested by Searle where some illocutionary force is negated rather than a proposition. ${ }^{6}$ If this is done, then also the air of paradoxicality involved in the Mādhyamika arguments seems to disappear.

To explain briefly: when a Mādhyamika refutes some position in a debate, it should be construed as what the Sanskrit philosophers call prasajya pratisedha, or simply pratisedha. I am now inclined to describe it as an act of illocutionary negation, where the speaker or the person who negates, assumes provisionally (cf. prasajya) something to be the case and then 'negates' it or rejects it. This negating act need not commit him to anything else except the rejection of what was assumed to be the case. A distinction between rejection and denial may be understood as follows: denial of something to be the case amounts to assertion of something not being the case, i.e., assertion of the falsity of that case. But rejection is non-assertive in withholding assent to something being the case, and this will then leave it open for us to withhold 
assent to the same thing not being the case. We may consider Searle's example in this light. "I do not promise to come" does not obviously constitute another 'negative' promise, and hence it is possible to say that I do not promise to come nor do I promise not to come. (In fact, I should say that I do not promise anything just as the Mādhyamika says, "I do not assert anything.")

\section{TWO LEVELS OF TRUTH}

A Mādhyamika, strictly speaking, is not a radical sceptic, but a Buddhist. Being a Buddhist, he must make a skilful use of the doctrine of the two levels of truth: the conventional or 'concealing' truth and the ultimate truth. For Nāgārjuna himself has warned:

Those who do not understand the distinction between these two truths, do not understand the deep significance of the Buddha's teaching. (Mk. 24.9)

In a way, it can be said that the doctrine of the two levels of truth is implicit in almost every metaphysical inquiry. A philosopher looks for the reality behind appearance, a doctrine of phenomena is circumscribed by a postulate of noumena, a reductionist tries to reach the basic elements out of which the gross world has been constructed, an analysis of physics makes room for the entrance of metaphysics. But the Mãdhyamika use of this doctrine of the two levels of truth is very different. The Mādhyamika does not ask us to penetrate through the seeming reality, the appearance, to reach the rock-bottom reality in the usual sense. For there is no rock-bottom reality to begin with (or to arrive at, as the case may be) except what our inherent tendency to misconceive and to misconstrue (cf., avidy $\bar{a}$ ) creates for us for the time being. Reality is emptiness, void, vacuity; or, to put the matter differently, the seeming reality or the appearance is all that there is and it is exactly as it is supposed to be, i.e., devoid of any 'own nature', of any essence, any value - it is empty. The 'concealing' reality does not, in fact, conceal anything, or what amounts to the same thing, it conceals EMPTINESS. Therefore, according to 
the Mādhyamika, the philosophers' search for the ultimate reality must end up in a quagmire of confusion, unless it leads him to Emptiness. To say that emptiness is the ultimate reality is again like the attempt to shout 'Silence' when all noises have already died down and hence it will only destroy silence. If the philosophers are looking for an ultimate reality, besides what is called the Appearance, a reality which is better and more secure than the Appearance, then the truth is that there isn't any such thing. The Appearance is the reality when it is properly understood. The samsāara is the nirvāna, says Nāgārjuna $(M k .25 .19) .{ }^{7}$ This realization of the vacuity, if the Buddha was right, is not, and should not be, horrifying, for it is the very essence of peace, it is bliss, it is sānta and siva. It is the cessation of all our discursive thoughts, all misguided drives and misconceived propensities and their attendant frustrations. It is prapancopaśama, ${ }^{8}$ 'a complete recovery from the malady of manifoldness'.

Professor Hsueh-li Cheng has prepared this annotated translation of the Chinese version of the Dväda'sa-dvära which will unearth further materials of the Mădhyamika philosophy for modern scholars. This will certainly stimulate further research in the history of Indian philosophy. More importantly, this, we hope, will also show the relevance of the study of the Mădhyamika texts in the present-day context. One of the express aims of our series has been to provide annotated translations of important philosophical texts of classical India. We have already presented two such volumes - one on Sriharșa and the other on Udayana (see Volumes 1 and 4). The present text is attributed to Nāgārjuna. I am sure the scholarly world in general, and Buddhologists in particular, will welcome this volume.

All Souls College, Oxford

BIMAL KRISHNA MATILAL

NOTES

1 Wing-tsit Chan, The Way of Lao Tzu, New York, 1963.

2 Anthony Kenny, The God of the Philosophers, Oxford, 1979, p. 4. 
3 Nyāyasūtra 1.2.3. sa pratipakșa-sthāpanā-hīno vitand $\bar{a}$. Here "sa" can refer to, according to Sānātani, either to "jalpah" in 1.2.2 or "vädah" in 1.2.1.

4 B. K. Matilal, Nyāya-Vaiseșika, Otto Harrassowitz, Wiesbaden, 1977, p. 92 .

5 B. K. Matilal, The Logical Illumination of Indian Mysticism, Oxford, 1977, pp. 10-14, and Notes 12 and 13.

6 J. Searle, Speech-Acts: An Essay in the Philosophy of Language, Cambridge, 1969 , pp. 32-33. My point is further discussed in B. K. Matilal: Logical and Ethical Issues in Religious Belief, Calcutta University, 1978, Stephanos Lectures (forthcoming).

7 Mr. Cheng, however, does not agree with this comment of mine.

8. Nāgārjuna, Madhyamaka-kārikāa (Mk.), Ch. 18, verse 9. 